\title{
Uterine Corpus Cancer pT4 TNM Finding v6
}

National Cancer Institute

\section{Source}

National Cancer Institute. Uterine Corpus CancerpT4 TNM Finding v6. NCI Thesaurus.

Code C61352.

Uterine corpus cancer with tumor invasion of the bladder mucosa or bowel mucosa.

Bullous edema is not sufficient to classify a tumor as T4. (from AJCC 6th Ed.) 